accepted normal range, this was not so in the atenolol-treated group. It seems likely from the data so far that all beta-blocking agents have similar effects, though the magnitude of such effects could depend on the so-called selectivity of the drug used. That differences not only of magnitude but possibly also of direction might occur is suggested by the observations of Newman ${ }^{10}$ that metoprolol failed to lower FFA concentrations compared with acebutolol and propranolol, and by those of Keene, ${ }^{16}$ who showed a rise in FFA concentrations in oxprenolol-treated diabetics. Thus the effects of different beta-blockers on various metabolic variables may be totally unrelated to their selectivity. ${ }^{3}$ Whatever the mechanism of action it would seem prudent to investigate all beta-blockers and other hypotensive agents for their effect on plasma triglyceride concentrations in view of the postulated association between these concentrations and the development of cardiovascular disease.

We thank ICI and Stuart Pharmaceuticals for financial support, and Mrs H Humphreys and Mrs A Osborne for technical help.

\section{References}

${ }^{1}$ Fain, J N, Pharmacological Revues, 1973, 25, 67.

${ }^{2}$ Robertson, R P, and Porte, D, jun, Diabetes, 1973, 22, 1.

${ }^{3}$ Day, J L, Metabolism, 1975, 24, 987.

${ }^{4}$ Lloyd-Mostyn, R H, et al, Atherosclerosis, 1971, 14, 283.

${ }^{5}$ Barboriak, J J, and Friedberg, H D, Atherosclerosis, 1973, 17, 31.

${ }^{6}$ Muller, H, Barthels, F, and Kluthe, R, Medizinische Klinik, 1973, 68, 634.

${ }^{7}$ Ghosh, P, Cochrane, A M G, and de Bono, D, Lancet, 1975, 1, 9.

${ }^{8}$ Tanaka, N, et al, Metabolism, 1976, 25, 1071.

${ }^{9}$ Waal-Manning, H J, and Simpson, F O, British Medical fournal, 1977, 2 , 705.

${ }^{10}$ Newman, R J, British Medical fournal, 1977, 2, 601.

${ }^{11}$ Nilsson, A, Hansson, B G, and Hokfelt, B, British Medical Fournal, 1977, 2, 126.

12 Bjorntorp, P, et al, Metabolism, 1970, 19, 631.

${ }_{13}$ Day, J L, Page, R L, and Metcalfe, J. In preparation.

14 Vizi, E D, Pagatsa, G, and Kaldor, A, Fournal of Pharmacy and Pharmacology, 1965, 17, 805.

${ }^{15}$ Ames, R P, and Hill, P, American fournal of Medicine, 1976, 61, 748.

${ }^{16}$ Keene, $\mathrm{H}$, personal communication.

(Accepted 26 October 1978)

\title{
Bacteriological quality control in human milk-banking
}

\author{
A LUCAS, C D ROBERTS
}

British Medical fournal, 1979, 1, 80-82

\section{Summary and conclusions}

The bacteriological quality of pooled human milk donated to the Oxford milk bank was analysed and the effects on bacteriology of sterilisation of the milkcollecting vessels in the home with hypochlorite solution and of Holder pasteurisation in a purpose-built humanmilk pasteuriser were studied. Collecting milk in hypochlorite-sterilised vessels resulted in a significantly lower bacterial count of both pathogens and species of unlikely pathogenicity before pasteurisation and significantly increased the chance of pasteurisation giving a sterile product. Potentially pathogenic organisms grown in untreated milk were Escherichia coli, Staphylococcus aureus, and group $B$-haemolytic streptococci. Seven species of organisms of unlikely pathogenicity were also identified. Pasteurisation eliminated all potential pathogens from milk but did not reliably remove any of the species of unlikely pathogens.

Banked human milk may be contaminated with bacteria which are known to be capable of producing lipases, proteases, and decarboxylases. Accurate pasteurisation, together with attention to the sterility of the collecting vessels, results in a bacteriologically safe product that retains many of the protective properties of raw milk.

\footnotetext{
University Department of Paediatrics, John Radcliffe Hospital, Oxford OX3 9DU

A LUCAS, MRCP, research fellow

UK Research and Development Laboratories, Vick International, Slough

C D ROBERTS, PHD, clinical trials manager
}

\section{Introduction}

Despite the re-emergence of human milk banks to provide milk for infants of low birth weight and sick infants in special-care baby units, optimal procedures in human milk-banking have not been defined. One unresolved problem is preserving the heatlabile antimicrobial components in human milk while making the milk bacteriologically safe for high-risk neonates. Accurate pasteurisation of milk results in relatively little damage to some of the major humoral protective factors in milk. ${ }^{1-3}$

We examined the bacteriological quality of milk donated to the Oxford milk bank before and after pasteurisation in a purpose-built human-milk pasteuriser. ${ }^{1}$ We also investigated the effect of using a hypochlorite sterilising agent during the collection procedure, since preliminary work in this department (Gibbs, unpublished observations) suggested that such simple antisepsis might influence the bacteriological outcome of pasteurisation.

\section{Methods}

The milk that drips from the opposite breast during breast-feeding is used to stock the Oxford milk bank. This drip breast milk is conveniently collected in a shell. ${ }^{1}$ During the study 60 donors contributed to the milk bank. They were allocated randomly into two groups.

Group 1-Donors in this group were issued with 120-ml plastic collecting vessels that had been washed in ordinary detergent. The donors were instructed to wash their collecting shells after each use and rinse them with tap water.

Group 2-Donors were told how to use a hypochlorite sterilising tank in which the collecting vessels, including the collecting shells, were sterilised before use.

In both groups mothers were instructed to wash their hands before handling collecting apparatus. Milk was collected in 24-hour samples, which were stored in the donors' domestic refrigerators. Every three or four days a district midwife brought the samples in a cooled container to the special-care baby unit, where the milk from each group was pooled separately. Twelve pools were studied, six from each group. Each pool comprised 75-120 24-hour collections from 25-30 donors. The pooled milk was pasteurised for 30 minutes at $62^{\circ} \mathrm{C}$ using the 
Oxford pasteuriser, which has an automated rapid heating and cooling cycle.

A specimen was taken from each milk pool before and after pasteurisation. Each sample was serially diluted out in tenfold steps and plated on to a series of general and selective media to isolate the aerobic and anaerobic flora. Bacterial counts are expressed as viable colony-forming units $/ \mathrm{ml}$ milk. The bacteriologist (CDR) was not told whether samples were from group 1 or group 2 pools.

Results were analysed statistically with Fisher's exact probability test, the Mann-Whitney rank sum test (for unpaired data), and the Wilcoxon matched pairs signed ranks test (for paired data).

\section{Results}

Table I shows the bacterial species grown in unpasteurised milk and their distribution in the two groups. The bacteria comprised three species of potential pathogens and seven species of unlikely pathogenicity. Colonisation with potential pathogens was equal in the two groups of pools, whereas three of the species of unlikely pathogens had a distribution that was associated with the mode of collectionyeasts and lactobacilli were significantly more common contaminants in group $1(\mathbf{P}<0.05$ and $\mathbf{P}<0.01$ respectively) and Propionibacterium acnes was significantly more common in group $2(\mathbb{P}<0.05)$. Unlikely pathogens colonised more milk pools than non-pathogens: Bacillus species, for example, colonised all 12 pools, and coagulase-negative staphylococci colonised 10 out of 12 pools. Mean bacterial counts (potential pathogens plus unlikely pathogens) were significantly lower in the six group 2 pools than in the six group 1 pools $(\mathbf{P}<0.05)$ (table II).

After pasteurisation all potential pathogens were eliminated, whereas organisms of unlikely pathogenicity were not reliably killed by this heat treatment, though the total bacterial counts were significantly reduced in both group $1 \quad(P<0.025)$ and group 2 $(P<0.025)$ (table II). When the mean bacterial counts after pasteurisation in group 1 and group 2 were compared the count in group 2 was

TABLE I-Influence of mode of collection on bacterial contamination in unpasteurised human milk. Figures represent number of pools contaminated (out of six) in each study group, with number of viable colony-forming units $\mathrm{ml}$ in parentheses

\begin{tabular}{|c|c|c|}
\hline & $\begin{array}{l}\text { Group } 1 \text { pools } \\
\text { (socially clean } \\
\text { collecting vessels) }\end{array}$ & $\begin{array}{l}\text { Group } 2 \text { pools } \\
\text { (hypochlorite-sterilised } \\
\text { collecting vessels) }\end{array}$ \\
\hline \multicolumn{3}{|c|}{ Potential pathogens } \\
\hline $\begin{array}{l}\text { Ecoli } \\
\text { Staph aureus } \\
\text { Group B } ; \text {-haemolytic streptococci }\end{array}$ & $\begin{array}{l}2\left(10^{5}, 10^{5}\right) \\
1\left(10^{5}\right) \\
0\end{array}$ & $\begin{array}{l}2\left(10^{4}, 10^{5}\right) \\
1(10) \\
1\left(10^{5}\right)\end{array}$ \\
\hline \multicolumn{3}{|c|}{ Unlikely pathogens } \\
\hline $\begin{array}{l}\text { Bacillus spp } \\
\text { Coagulase-negative staphylococci } \\
\text { Yeasts (not Candida } \mathrm{spp} \text { ) } \\
\text { Lactobacilli } \\
\text { Pacnes } \\
\text { Non-faecal Gram-negative bacilli } \\
S \text { faecalis }\end{array}$ & $\begin{array}{l}6\left(10^{7}\right) * \\
4\left(10^{4}\right)^{*} \\
6\left(10^{6}\right)^{*} \\
6\left(10^{6}\right)^{*} \\
0\left(10^{3}, 10^{7}\right) \\
2\left(10^{7}\right)\end{array}$ & $\begin{array}{l}6\left(10^{5}\right)^{*} \\
6\left(10^{4}\right)^{*} \\
2\left(10,10^{5}\right) \\
1\left(10^{4}\right) \\
4\left(10^{5}\right)^{*} \\
0 \\
0\end{array}$ \\
\hline
\end{tabular}

*Figures represent mean counts $/ \mathrm{ml}$.

TABLE II-Effect of mode of collection on log number of colony-forming units/ml of milk before and after pasteurisation

\begin{tabular}{lcc}
\hline & $\begin{array}{c}\text { Group 1 pools } \\
(\mathrm{n}=6)\end{array}$ & $\begin{array}{c}\text { Group 2 pools } \\
(\mathrm{n}=6)\end{array}$ \\
\hline $\begin{array}{l}\text { Before pasteurisation } \\
\text { After pasteurisation }\end{array}$ & $\begin{array}{l}7.07+0.56 \\
3.09+1.56\end{array}$ & $\begin{array}{c}5.50+1.08 \\
0.99+0.56\end{array}$ \\
\hline
\end{tabular}

TABLE III-Number of milk pools in each group that were sterile after pasteurisation

\begin{tabular}{lcc}
\hline & Sterile & Not sterile \\
\hline Group 1 (socially clean vessels) & 0 & 6 \\
Group 2 (sterile vessels) & 4 & 2 \\
\hline
\end{tabular}

significantly lower $(\mathbf{P}<0.05)$ (table II). Furthermore, a significantly greater number of group 2 pools compared with group 1 pools were sterile after pasteurisation (table III).

\section{Discussion}

We have shown that potentially pathogenic organisms ( $E$ coli, Staph aureus and group B $\beta$-haemolytic streptococci) ${ }^{4}$ were present in high counts in pooled human milk and were eliminated using a purpose-built human milk pasteuriser. In contrast, bacterial species of unlikely pathogenicity were sometimes present in milk after pasteurisation, as would be expected from their known heat sensitivity. Nevertheless, sterilising collecting vessels at home with a hypochlorite sterilising agent significantly reduced the degree of bacterial contamination before and after pasteurisation and increased the proportion of milk pools that were sterile after pasteurisation.

Heavy bacterial contamination of milk may be undesirable, since among the organisms that we identified in human milk were bacteria that produce lipases, proteases, or decarboxylases in dairy products. ${ }^{5-8}$ Such enzymes might produce some of the unwanted effects suggested in table IV. Further work is needed

TABLE IV-Theoretical undesirable effects of bacterial products in banked human milk

\begin{tabular}{|c|c|c|}
\hline Organism & Product & Hypothetical effect \\
\hline $\begin{array}{l}\text { Gram-negative non-faecal } \\
\text { bacilli (especially } \\
\text { pseudomonas), Staph aureus }\end{array}$ & Lipases & $\begin{array}{l}\text { Release of free fatty acids may } \\
\text { lead to neonatal jaundice }\end{array}$ \\
\hline $\begin{array}{l}\text { Bactllus spp, Gram-negative } \\
\text { non-faecal bacilli }\end{array}$ & Proteases & $\begin{array}{l}\text { Possible damage to protective } \\
\text { components such as } \\
\text { immunoglobulins }\end{array}$ \\
\hline Faecal streptococci, $E$ coli & Decarboxylases & $\begin{array}{l}\text { Convert free amino-acids to } \\
\text { amines such as tyramine and } \\
\text { tryptamine. Possibly toxic to } \\
\text { neonate }\end{array}$ \\
\hline
\end{tabular}

to establish whether these indirect effects of bacterial contamination are important in human milk-banking. The possible generation of biologically active amines in milk as a result of bacterial decarboxylase activity may be particularly important. Amines such as tyramine, tryptamine, and histamine, derived from the corresponding amino-acids, have been detected in dairy products, and others have commented on their potential undesirable pathophysiological effects. ${ }^{8}$ Little is known about either the presence of these substances in heavily contaminated human milk or the susceptibility of preterm infants to them. Extrapolating from the findings of the dairy industry, the degree and duration of contamination that we observed in milk pools from group 2 (sterilised collecting vessels) were unlikely to have resulted in appreciable extracellular enzyme production. ${ }^{9} 10$

The possibility of staphylococcal enterotoxin persisting after pasteurisation has been discussed by others. ${ }^{11}$ Roughly $30^{\circ}$ o of coagulase-positive staphylococci produce an enterotoxin, but are unlikely to do so in the presence of profuse contamination with saprophytic organisms, ${ }^{12}$ which was the case in milk pools from our donors. We are investigating whether this enterotoxin can be detected in banked milk. The enterotoxin produced by Bacillus cereus might also be present in raw milk, though we have never identified $B$ cereus among the bacillus species cultured. This enterotoxin has been responsible for many outbreaks of food poisoning. Unlike staphylococcal enterotoxin, however, it is heat labile and destroyed by pasteurisation. ${ }^{13}$

The Oxford milk bank uses milk that has been stored in a domestic refrigerator in the donor's home for three to four days. This milk has a high bacterial count, which largely comprises saprophytic organisms capable of rapid growth during lowtemperature storage (psychrotrophic organisms). Other units have achieved cleaner milk, but only by using a more elaborate milk collection routine that relies on time-consuming and expensive bacteriological monitoring of individual donations and discarding a substantial proportion of milk contributed. We are 
investigating the effects of home storage of frozen milk. Although lower bacterial counts might be expected, this benefit needs to be weighed against the possible damage incurred by excessive freezing to protective components in milk. ${ }^{1}$

We conclude that if milk is collected in the way we have described, into vessels sterilised at home with hypochlorite solution, precise pasteurisation results in a bacteriologically acceptable product and obviates the need for complex and expensive milk-banking procedures.
3 Evans, T J, et al, Archives of Disease in Childhood, 1978, 53, 239.

${ }^{4}$ Lucas, A, and Roberts, C D, British Medical fournal, 1978, 1, 919.

5 Law, B A, Sharpe, M E, and Chapman, H R, Fournal of Dairy Research, $1976,43,459$.

${ }^{6} \mathrm{Law}, \mathrm{B}$ A, et al, Society for Applied Bacteriology, Technical Series. In press. Dahlberg, A C, and Kosikowski, F V, Fournal of Dairy Science, 1948, 31, 305.

${ }^{8}$ Voigt, M N, and Eitenmiller, R R, fournal of Food Protection, 1977, 40, 241.

9 Cousins, C M, Sharpe, M E, and Law, B A, Dairy Industries International, $1977,42,12$.

${ }^{10}$ Law, B A, personal communication

11 Williamson, S, et al, British Medical fournal, 1978, 1, 393.

12 Frobisher, M, Fundamentals of Microbiology, 8th edn, p 415. Philadelphia, W B Saunders, 1968.

13 WHO Technical Report Series No 598, p 29. Geneva, WHO, 1976.

1 Gibbs, J H, et al, Early Human Development, 1977, 1, 227

2 Ford, J E, et al, fournal of Pediatrics, 1977, 90, 29.

\title{
Detection of deep venous thrombosis by scanning of ${ }^{99 m}$ technetium-labelled red-cell venous pool
}

\author{
W BESWICK, R CHMIEL, R BOOTH, I VELLAR, E GILFORD, C N CHESTERMAN
}

British Medical fournal, 1979, 1, 82-84

\section{Summary and conclusions}

A comparative study of 32 patients with suspected deep venous thrombosis was carried out using blood-pool radionuclide scanning and conventional $x$-ray phlebography. Results of the two methods showed close agreement, the sensitivity (positive correlation) of the scan being $100 \%$ and its specificity $89 \%$.

We conclude that a patient's red cells labelled with $99 \mathrm{~m}$ technetium ( $\left.{ }^{9 \mathrm{~m}} \mathrm{Tc}\right)$ provide an excellent medium for this type of scanning. The technique has particular advantages in visualising the whole venous system, giving a persisting image, and obviating the need to inject into a vein of the affected limb. In view of the inherent disadvantages of contrast phlebography, ${ }^{99} \mathrm{mTc}-$ red-cell scanning is clearly an acceptable alternative.

\section{Introduction}

The detection of deep venous thrombosis poses a definite diagnostic problem. Prospective isotopic screening of patients at risk of developing thrombosis has shown that clinically silent venous thrombosis is common. Furthermore, over $45 \%$ of patients with symptoms suggestive of deep venous thrombosis have no phlebographically detectable thrombus. ${ }^{1}$ Ascending phlebography remains accepted as the most reliable investigation available but is an unpleasant procedure that is technically

\footnotetext{
Department of Medicine, University of Melbourne, Melbourne, Australia

W BESWICK, MB, BS, lecturer

C N CHESTERMAN, DPHIL, FRACP, first assistant

St Vincent's Hospital, Melbourne, Australia

R CHMIEL, DTR, MRACR, director of nuclear medicine

R BOOTH, NMT, senior technologist, department of nuclear medicine

I VELLAR, FRCS, FRACs, surgeon

E GILFORD, MRACR, FFR, director of radiology
}

demanding and in a few cases may be responsible for initiating venous thrombosis. ${ }^{2} 3$

Red blood cells are quickly and easily labelled with ${ }^{9}{ }^{9} \mathrm{~m}$ technetium $\left({ }^{99 \mathrm{mT}} \mathrm{T}\right){ }^{4}$ One of us (RC) has found that labelled cells outline the blood pool in the venous system with such resolution that venous anatomy is delineated and thrombi localised with good accuracy. We carried out this study to compare the results obtained by scanning the $99 \mathrm{~m}$ Tc-labelled red-cell blood pool with those obtained by $x$-ray contrast phlebography in 32 patients investigated for deep venous thrombosis over seven months.

\section{Patients and methods}

We included in the study patients who were referred to the diagnostic services of the radiology and nuclear medicine departments between July 1977 and February 1978 for investigation of possible deep venous thrombosis. These patients underwent ${ }^{99 \mathrm{~m}} \mathrm{Tc}$-red-cell scanning and ascending phlebography.

\section{9m TC-RED-CELL SCANNING}

We mixed 3-5 $\mathrm{ml}$ of venous blood from the patient with $1 \mathrm{ml}$ of acid-citrate-dextrose anticoagulant and incubated this for five minutes at room temperature with two drops of pyrophosphate (Mallinckrodt Pyrophosphate Kit reconstituted with $2 \mathrm{ml}$ of $0.15 \mathrm{M} \mathrm{NaCl}$ ). The cells were washed twice with $0 \cdot 15 \mathrm{M} \mathrm{NaCl}$ and incubated with $10 \mathrm{mCi}$ ${ }^{99} \mathrm{TcO}_{4}$ for five minutes at room temperature. The labelled cells were again washed twice and made up to $3 \mathrm{ml}$ with $0 \cdot 15 \mathrm{M} \mathrm{NaCl}$ before injection.

For imaging we used a gamma-camera with a large field of view (Toshiba GCA 401). In general, the ${ }^{99 \mathrm{~m}} \mathrm{Tc}$-labelled red cells were injected into an antecubital vein and imaging begun after five minutes. When dorsal veins of the foot were easily accessible we used these for injection so that the progress of blood flow through the upper femoral and iliac areas could be viewed with the gamma-camera. After injection into the foot 10 minutes elapsed before blood-pool imaging was begun to permit equilibration. Images of the blood pool were obtained in three views: an anterior view of the iliac and upper femoral area, an anterior view of the thighs, and a posterior view of the calves including the popliteal vessels.

A normal pattern was easily recognisable (fig 1). Partial obliteration of segments along the major vessels was interpreted as deep venous thrombosis. This appearance was generally accompanied by increased 